\title{
Dampak Pandemic Covid- 19 Terhadap Indeks Pembangunan Ekonomi Inklusif Jawa Timur Indikator Tingkat Kemiskinan Dan Ketimpangan
}

\author{
Anis Rahmawati ${ }^{1}$, Layna Lutfiani², Zulvita Rahma Yunia ${ }^{3}$, Isma'iddatur Rofiqoh4, Fitri \\ Fatimatuz Zahrok, dan Destiana Wahyuningtyas ${ }^{5}$. \\ anisa.ryc1@gmail.com¹ ${ }^{1}$, Laynalutfiani@gmail.com², rahmazulvita@gmail.com³ \\ ismanyus@gmail.com , fatimatuzzahrok@gmail.com ${ }^{5}$, dan destihana12@gmail.com6 \\ Program Magister Studi Ekonomi Syariah \\ Pascasarjana Institut Agama Islam Negeri Tulungagung 1,2,3,4,5,6
}

\begin{abstract}
Abstrack
This research uses descriptive quantitative approach. The purpose of this research is to find out how the Covid 19 pandemic affects the inclusive economic development index. To conduct this research, the method used is quantitative method with statistical tests between dependent variables and independent variables in order to provide results that can be explained by numbers. It is based on data analysis and relevant data collection techniques obtained from previous studies and the official website that published the data. Sources of data in this study use secondary data. The data is in the form of documents and reports, which are in the form of an overview of the research location and data relevant to a study. Researchers used data collection techniques from various scientific journal literatures that were reviewed and processed. The results of the test show that there is a significant effect between Covid 19 on inclusive economic growth in East Java. Where the Covid-19 Virus pandemic has had a number of significant impacts in the domestic economic sector and on the existence of MSMEs in the country and nation. The impact of Covid-19, which has caused economic shock, also greatly affects the economy, both individually, micro, small, and medium enterprises, the country's economy which includes local, national and global levels.
\end{abstract}

Keywords: the impact of COVID-19, the poverty rate, the level of Inequality

\begin{abstract}
Abstrak
Penelitian ini menggunakan metode pendekatan kuantitatif deskriptif. Tujuan peneltian ini, untuk mengetahui bagaimana pengaruh adannya pandemi Covid 19 terhadap indeks pembangunan ekonomi inklusif. Untuk melakukan penelitian tersebut, metode yang digunakan yakni metode kuantitatif dengan uji statistika antar variabel dependen denganvariabe independen guna memberikan hasil yang dapat dijelaskan dengan angka. Hal tersebut didasarkan pada analisis data dan tekhnik pengumpulan data yang sudah relevan yang diperoleh dari berbagai penelitian terdahulu dan situs resmi yang mengeluarkan data tersebut. Sumber data dalam penelitian menggunakan data sekunder. Data tersebut berupa dokumen-dokumendan laporan-laporan, yang berupa suatu gambaran umum mengenai lokasi penelitian serta data yang relevan dengan sebuah penelitian. Peneliti menggunakan teknik pengumpulan data dari berbagai literature jurnal ilmiah yang ditelaah serta diolah. Hasl uji menunjukkan bahwasannya adannya pengaruh yang signiikan antara covid 19 terhadap pertumbuhan ekonomi inklusi jawa timur. Dimana pandemi Virus Covid-19 telah menimbulkan berbagai dampak yang cukup signifikan di sektor perekonomian domestic dan pada keberadaan UMKM di negara dan bangsa. Dampak dari Covid-19 yang sudah menyebabkan economic shock, juga sangat berpengaruh terhadap ekonomi,baik secara perorangan usaha mikro kecil menengah, perekonomian negara yang mencangkup dari local, nasional serta global.
\end{abstract}

Kata Kunci: dampak Covid-19, tingkat kemiskinan, tingkat ketimpangan

\section{PENDAHULUAN}

Pertumbuhan ekonomi telah menjadi permasalahan makro yang berjangka panjang pada setiap periode tertentu dan selalu mengupayakan untuk melakukan peningkatan pada perekonomian daerah supaya tercipta kesejahteraan masyarakat dengan cara meningkatkan 
Anis Rahmawati, L. Lutfiani, Zulvita R. Yunia, Isma'iddatur Rofiqoh, Fitri F. Zahrok, \& D. Wahyuningtyas.

berbagai macam faktor yang sangat mempengaruhi terhadap pertumbuhan ekonomi secara makro, dengan di upayakan nya peningkatan maka faktor tersebut akan mengalami peningkatan yang cukup baik. Tenaga kerja dan Investasi yang di gunakan sebagai pembentukan modal dan perdagangan inter nasional yang telah ditetapkan di dalam teori makro ekonomi sebagai input atau sebagai faktor penunjang dalam pertumbuhan ekonomi optimal yang terdapat di regional tertentu.

Syahrul et.al (2018) Pertumbuhan ekonomi adalah sebuah indikator yang mempunyai peranan penting dalam penilaian suatu kinerja perekonomian terutama dalam hal análisis tentang suatu hasil pembangunan perekonomian yang sudah dilaksanakan di suatu daerah atau suatu negara tertentu. Pertumbuhan ekonomi pada suatu negara dapat dikatakan mengalami suatu pertumbuhan apabila produksi pada barang maupun jasa telah mengalami peningkatan dari waktu ke waktu. Dengan adanya demikian suatu pertumbuhan perekonomian sejauh ini menunjukkan aktivitas ekonomi yang bisa menghasilkan tambahan atas pendapatan maupun kesejahteraan masyarakat di waktu tertentu. Pertumbuhan pada ekonomi pada suatu wilayah atau pada suatu negara yang selalu menunjukkan suatu peningkatan, itu menggambarkan suatu wilayah atau negara tersebut mengalami perkembangan ekonomi yang sangat baik.

Suatu proses pembangunan membutuhkan pertumbuhan ekonomi cepat dan pendapatan nasional yang cukup tinggi. Di berbagai negara pertumbuhan ekonomi menjadi syarat utama supaya tercipta penurunan kemiskinan. Dengan adanya peningkatan ekonomi yang memang belum cukup untuk menyelesaikan masalah kemiskinan, namun itu pun menjadi suatu yang sangat diperlukan. Pada kenyataan tersebut menjelaskan bahwa pertumbuhan perekonomian yang cukup tinggi tidak begitu berarti bagi menurunnya tingkat kemiskinan masyarakat bila tidak di ikuti dengan adanya pemerataan pendapatan.

Pertumbuhan ekonomi pada suatu regional yaitu pertambahan atas pendapatan suatu masyarakat yang secara menyeluruh yang terdapat pada suatu wilayah atau regional tersebut, pada kebaikan nilai tambah dan kenaikan keseluruhan yang telah terjadi. Ambok (2018) Agar mampu melihat suatu pertambahan dari waktu ke waktu yang berikutnya, harus di tetapkan dengan nilai yang riil, yang berarti itu di tetapkan dengan harga yang konstan. Pada penerapan tersebut harus mengaitkan berbagai ruang lingkup di wilayah operasi tersebut, seperti pada daerah dan wilayah yang tidak mempunyai suatu kekuasaan untuk dapat membuat kebijakan moneter dan kebijakan fiskal, suatu wilayah dapat lebih terbuka pada pergerakan orang atau barang.

Kemiskinan merupakan suatu keadaan dimana sering berhubungan dengan kesulitan dan kekurangan kebutuhan di segala kehidupan. Kemiskinan juga diartikan sebagai suatu yang tidak mempunyai seseorang untuk memenuhi kebutuhan atas konsumsi dasar untuk meningkatkan kualitas kehidupannya. Ukuran kemiskinan di bagi menjadi dua macam yaitu kemiskinan relative dan kemiskinan absolut. Kemiskina relative adalah suatu kemiskinan yang berkaitan dengan adanya perbedaan tingkat pendapatan pada golongan yang satu dengan suatu golongan yang lain, sedangkan kemiskinan absolut adalah tidak mempunyai seseorang untuk melampaui suatu garis kemiskinan yang telah di tetapkan.

Kemiskinan itu juga merupakan suatu masalah yang terdiri dari beberapa aspek karena memiliki kaitan dengan pendapatan rendah, kesehatan yang cukup rendah, perbedaan derajat antara jenis kelamin, melemahnya pada lingkungan kehidupan, serta buta huruf. Bank Dunia 
Anis Rahmawati, L. Lutfiani, Zulvita R. Yunia, Isma'iddatur Rofiqoh, Fitri F. Zahrok, \& D. Wahyuningtyas.

menjelaskan bahwa salah satu adanya penyebab dari kemiskinan yaitu kurangnya pendapatan yang digunakanuntuk memenuhi suatu kebutuhanmendasar misalnya rumah, pakaian, dan makanan, serta tingkat kesehatan dan pendidikan yang rendah. Dalam mengatasi adanya masalah kemiskinan itu tidak bisa terlepas dari masalah pendidikan, kesehatan, dan pengangguran, dan beberapa masalah yang sangat berkaitan pada masalah kemiskinan.

Ilham (2015) Ketimpangan ekonomi adalah suatu permasalahan yang cukup kompleks yang dapat dipengaruhi oleh bermacam - macam aspek. Aspek yang mempengaruhi suatu ketimpangan bukan hanya dari aspek sumbar daya manusia saja, melainkan aspek alam juga mempengaruhi seperti potensi sumber daya alam dan karakteristik geografis. Dengan tidak meratanya pembangunan di antar daerah di Indonesia dapat menyebabkan ketimpangan ekonomi suatu daerah atau wilayah dengan daerah atau wilayah lainnya.

Pada bulan maret 2020 dilaman resmi badan pusat statistika menyebutkan bahwasannya tingkat ketimpangan suatu penduduk pada Provinsi Jawa Timur yang telah diukur oleh Gini Ratio yaitu sebesar 0,382. Angka ini telah meningkat sekitar 0,001\%, dibandingkan Gini Ratio pada bulan September 2019 yaitu sebesar 0,380 dan data ini menurun sebesar $0.001 \%$ dibandingkan dengan Gini Ratio bulan Maret 2019 sebesar 0,382.Berdasar ketimpangan Provinsi Jawa Timur, distribusi pengeluaran di tingkat $40 \%$ terbawah sebesar $17,73 \%$. Berdasarkan data tersebut pengeluaran penduduk di bulan Maret 2020 merupakan kategori pada tingkat ketimpangan yangrendah. Apabila dirinci menurut daerah atau wilayah daerah perkotaan yang angkanya sudah tercatat sebesar $16,93 \%$ tergolong di kategori ketimpangan yang sedang.

BPS (2020) Menurut Gini Ratio ukuran pada suatu ketimpangan yang biasa digunakan adalah presentase pada pengeluaran di kelompok penduduk sebesar $40 \%$ terbawah. Ukuran suatu tingkat ketimpangan dapat dibagi jadi 3 kategori yaitutingkat ketimpangan yang tinggi apabila presentase pengeluaran di kelompok penduduk sebesar $40 \%$ terbawah dengan angka dibawah $12 \%$ dan ketimpangan yang sedang jika angkanya sekitar antara $12-17 \%$, serta ketimpangan yang rendah terjadi jika angka diatas $17 \%$.

Tabel 1. Tabel Distribusi Pengeluaran Penduduk Provinsi Jawa Timur Bulan Maret 2019, September 2019, dan Maret 2020 (Presentase)

\begin{tabular}{|c|c|c|c|c|}
\hline Daerah/Tahun & $\begin{array}{l}\text { Penduduk } 40 \% \\
\text { terbawah }\end{array}$ & $\begin{array}{l}\text { Penduduk } 40 \% \\
\text { menengah }\end{array}$ & $\begin{array}{l}\text { Penduduk } 20 \% \\
\text { teratas }\end{array}$ & Jumlah \\
\hline (1) & (2) & (3) & (4) & (5) \\
\hline \multicolumn{5}{|l|}{ Perkotaan } \\
\hline Maret 2019 & 16,93 & 37,09 & 45,98 & 100 \\
\hline September 2019 & 16,90 & 37,25 & 45,85 & 100 \\
\hline Maret 2020 & 16,93 & 36,94 & 46,13 & 100 \\
\hline \multicolumn{5}{|l|}{ Pedesaan } \\
\hline Maret 2019 & 20,59 & 39,67 & 39,74 & 100 \\
\hline September 2019 & 20,6 & 39,76 & 39,58 & 100 \\
\hline Maret 2020 & 20,62 & 39,61 & 39,77 & 100 \\
\hline \multicolumn{5}{|c|}{ Perkotaan+Pedesaan } \\
\hline Maret 2019 & 17,71 & 36,81 & 45,48 & 100 \\
\hline September 2019 & 17,71 & 36,93 & 45,36 & 100 \\
\hline Maret 2020 & 17,73 & 36,78 & 45,49 & 100 \\
\hline
\end{tabular}

Sumber: Badan pusat statistika 2020 (diolah) 
Anis Rahmawati, L. Lutfiani, Zulvita R. Yunia, Isma'iddatur Rofiqoh, Fitri F. Zahrok, \& D. Wahyuningtyas.

Untuk dapat mengantisipasi dampak dari pandemi covid-19 terhadap pembangunan ekonomi di sektor kemiskinan dan ketimpangan, pemerintah dapat mengupayakan dengan meningkatkan usaha mikro kecil dan menengah (UMKM) di kalangan masyarakat, untuk dapat meningkatkan perekonomian negara dan masyarakat. Adanya usaha mikro kecil dan menengah (UMKM) ditengah masyarakat dapat mengurangi kemiskinan dan ketimpangan bagi warga negara Indonesia, serta pemerintah dapat memberikan sumbangan dana bagi usaha mikro kecil dan menengah (UMKM) dalam mengembangkan suatu usaha yang dimiliki masyarakat akibat pandemi covid- 19 pada seperti saat ini yang menimbulkan dampak terhadap pendapatan warga masyarakat Indonesia.

Sejak terjadinya pandemi Covid-19 ini pada Kota Wuhan pihak dari pemerintah langsung mengeluarkan kebijakan lockdown dan pembatasan wilayah di seluruh RRC. Pandemi Virus Covid-19 atau Corona Virus Disease 2019 di umumkan oleh organisasi WHO (World Health Organization) yaitu pada tanggal 11 Maret 2020 dan pada tanggal 31 Januari 2020 di umumkan pertama kalinya di kota Wuhan provinsi Hubei, Republik Rakyat Cina. Pada minggu ke empat di bulan April tahun 2020 sudah terdapat kurang lebih 10.118 kasus di Indonesia sebagaimana yang dikemukakan oleh danu (2020) di detik.com Bapak Presiden Jokowi Dodo mengumumkan terjadinya virus Covid-19 di negara Indonesia pertama kali yaitu pada tanggal 02 Maret tahun 2020 dan menetapkan virus tersebut selaku bencana (disaster). Secara khusus BNPB (Badan Nasional Penanggulangan Bencana) menyebutkan Virus Covid-19 adalah sebuah bencana yang tidak alami (non natural disaster) yang telah mencangkup pada skala nasional. Pada penelitian terdahlu milik taufik et al (2020) dijelaskan bahwa pada tahun 2003 juga telah terjadi kasus seperti Virus Covid-19 yang dinamakan dengan Virus SARS yang menyebabkan perekonomian Indonesia berjalan lambat 0,03 \% di bandingkan dengan Virus SARS, Virus Covid-19 mempunyai tingkat penyebaran penyakit yang lebih cepat dan menimbulkan kematian korban jiwa lebih tinggi.

Akhnolt dan taufiq dalam penelitiannya menyebutkan bahwa pandemi Virus Covid-19 telah banyak memberikan dampak yang cukup besar terhadap bermacam-macam sektor. Di era ekonomi global saaat ini pandemi Virus Covid-19 telah menimbulkan berbagai dampak yang cukup signifikan di sektor perekonomian domestic dan pada keberadaan UMKMdi negara dan bangsa. Dampak dari Covid-19 yang sudah menyebabkan economic shock, juga sangat berpengaruh terhadap ekonomi,baik secara perorangan usaha mikro kecil menengah, perekonomian negara yang mencangkup dari local, nasional serta global.

Pada OECD (OrganisationForEconomic Co-operation and Development) menyatakan pandemi virus ini telah berimplikasi pada ancaman sebuah krisis perekonomian yang cukup besar dengan ditandai terhentinya sebagian aktivitas dan sebagian produksi di berbagai bangsa dan negara, menurunnya tingkat konsumsi di masyarakat, dan hilangnya sebagian kepercayaan dari konsumen, menurunnya bursa saham dan mengarah pada ketidakpastian. Bila hal tersebut berkelanjutan, OECD memperkirakan bisa mengakibatkan menurunnya seperlima hingga seperempat tingkat output di berbagai negara. Prediksi ini juga akan mengancam perekonomian pada negara Indonesia. AknoltKristianPakpahan telah menyebutkan adanya beberapa implikasi di negara Indonesia yang disebabkan oleh pandemi Virus Covis-19 yaitu sector investasi, pariwisata, dan perdagangan. Negara Indonesia yang keberadaannya UMKM (Usaha Mikro, Kecil, dan Menengah) mendominasi menjadi tulang punggung ekonomi negara bisa memiliki 
Anis Rahmawati, L. Lutfiani, Zulvita R. Yunia, Isma'iddatur Rofiqoh, Fitri F. Zahrok, \& D. Wahyuningtyas.

dampak yang sangat serius yaitu pada aspek nilai perdagangan dan total produksi serta pada beberapa tenaga kerja yang harus terkena PHK (Pemutusan Hubungan Kerja) Virus Covid-19 ini.

Berdasarkan latar belakang tersebut, maka kami tertarik untuk melakukan penelitian terkait adakah dampak yang ditimbulkan akibat adannya wabah covid 19. Terkhusus pada pertumbuhan ekonomi masyarakat Indonesia. Dimana, dalam hal ini, kita mengkususkan pada variabel kemiskinan dan ketimpangan guna dilakukan pengujian lebih lanjut dan mendalam.

\section{METODE PENELITIAN}

Penelitian ini menggunakan metode pendekatan kuantitatif deskriptif. Subagyo (2017) Yang dimaksud dengan penelitian kuantitatif adalah jenis penelitian yang dapat menghasilkan penemuan-penemuan yang menggunakan berbagaiprosedur statistik maupunmemakai carayang lain dari kuantifikasi dalam suatu pengukuran. Sumber Data dalam penelitian menggunakan data sekunder. Data Sekunder yaitu data yang dikumpulkan oleh peneliti dari sumber yang telah ada. Data tersebut berupa dokumen-dokumendan laporan-laporan, yang berupa suatu gambaran umum mengenai lokasi penelitian serta data yang relevan dengan sebuah penelitian. Peneliti menggunakan teknik pengumpulan data dari berbagai literature jurnal ilmiah yang ditelaah serta diolah. Metode dan tekhnik dari pengumpulan data yaitu cara yang dilakukan peneliti yang digunakan untuk mengumpulkan berbagai data yang diperlukan dalam penelitian. Pengumpulan data berasal dari situs resmi bps yang diolah menggunakan spss dengan beberapa uji statistika sederhana. Yang kemudian, hasil pengujian diinterpretasikan dalam bentuk deskriptif.

\section{HASIL DAN PEMBAHASAN}

Untuk mengetahui berbagai dampak Pandemi Virus Covid-19 terhadap indeks pertumbuhan ekonomi inkluasif Jawa Timur, studi kasus pada kemiskinan dan ketimpangan. Maka salah satunnnya dapat dilihat dari perubahan laju kemiskinan di Jawa Timur antara sesudah Pandemi Virus Covid-19 dengan membandingkan pertumbuhan kemiskinan di Jawa Timur sebelum adannya Pandemi Virus Covid-19.

Tabel 2. Data kemiskinan Jawa Timur Maret 2015-Maret 2020

\begin{tabular}{lc}
\hline Bulan dan Tahun & Data Proyeksi \\
\hline Maret 2015 & 12,34 \\
\hline September 2015 & 12,28 \\
\hline Maret 2016 & 12,05 \\
\hline September 2016 & 11,85 \\
\hline Maret 2017 & 11,77 \\
\hline September 2017 & 11,20 \\
\hline Maret 2018 & 10,98 \\
\hline September 2018 & 10,85 \\
\hline Maret 2019 & 10,37 \\
\hline September 2019 & 10,20 \\
\hline Maret 2020 & 11,09
\end{tabular}

Sumber data:Dari situs resmi BPS jawa timur 2020

Pada data tersebut terlihat bahwasannya pertumbuhan perekonomian di Jawa Timur sebelum adannya pandemi covid 19 menunjukkan perkembangan yang sangat bagus. Hal tersebut dapat terlihat dari prosentase angka kemiskinan yang cenderung selalu menunjukkan pengurangan angka pada bulan dan tahun setelahnya. Sebagai contoh nyata sebelum adannya 
Anis Rahmawati, L. Lutfiani, Zulvita R. Yunia, Isma'iddatur Rofiqoh, Fitri F. Zahrok, \& D. Wahyuningtyas.

Pandemi Virus Covid-19. Terlihat bahwasannya dibulan Maret 2015 jumlah kemiskinan di Jawa Timur masuk diangka 12,34. Pada tahun dan bulan ini, tingkat kemiskinan di Jawa Timur masih relatif sangat tinggi. Namun, dibulan selanjutnya, tepatnya di bulan September 2015. Angka kemiskinan di Jawa Timur mengalami penurunan sebesar 0,6. Dimana sebelumnya diangka 12,34 menjadi 12,28. Hal tersebut menunjukkan bahwasannya angka kemiskinan di Jawa Timur semakin hari semakin menunjukkan kondisi yang positif. Dengan demikian, bisa dikatakan bahwatingkat suatu kesejahteraan pada masyarakat semakin lebih meningkat dibulan dan tahun setelahnya. Hal tersebut dapat dilihat dari data pegolahan spss dibawah ini.

\begin{tabular}{ll}
\hline \multicolumn{1}{c}{ Statistics } \\
\hline MAR11_MAR20 & 11 \\
\hline Valid & 0 \\
\hline Missing & 11.3618 \\
\hline Mean & 11.2000 \\
\hline Median & $10.20 \mathrm{a}$ \\
\hline Mode & .74295 \\
\hline Std. Deviation & .552 \\
\hline Variance & -.160 \\
\hline Skewness & .661 \\
\hline Std. Error of Skewness & -1.266 \\
\hline Kurtosis & 1.279 \\
\hline Std. Error of Kurtosis & 2.14 \\
\hline Range & 10.20 \\
\hline Minimum & 12.34 \\
\hline Maximum & 124.98 \\
\hline Sum &
\end{tabular}

Selain bulan maret 2015 dan september 2015. Penurunan angka kemiskinan juga menunjukkan angka yang sangat bagus dan terus mengalami penurunan. Hal tersebut terlihat hingga pada bulan september 2019 yang terus mengalami penurunan. Sampai dimana titik kemiskinan mengalami penurunan yang sangat banyak hingga pada titik 10,20. Hal tersebut menunjukkan bahwa, masyarakat cenderung mengalami kenaikkan kesejahteraan yang ditandai dengan tingkat kemiskinan yang mengalami penurunan dari bulan sebelumnya ke bulan berikutnya.

Namun, hal yang tak terduga dan diluar kendali manusia mulai terjadi pada bulan maret 2020. Dimana mulai datang pasukan bersenjata yang tak nampak, namun, memberikan imbas dan dampak yang sangat signifikan terhadap jumlah kemiskinan di Jawa Timur. Dimana, tingkat kemiskinan yang sebelumnya selalu menunjukkan tanda yang positif untuk kesejahteraan masyarakat. Kini mulai perlahan turun karna adannya dampak Pandemi Virus Covid-19.

Ketika Pandemi Virus Covid-19 mulai merajalela dan berkembang di tengah kehidupan masyarakat. Maka hal tersebut tentunnya sangat mengusik kesejahteraan masyarakat. Dampak yang ditumbulkannya, salah satunnya perekonomian masyarakat cenderung berhenti karna 
Anis Rahmawati, L. Lutfiani, Zulvita R. Yunia, Isma'iddatur Rofiqoh, Fitri F. Zahrok, \& D. Wahyuningtyas.

banyak dari masyarakat yang merasa takut terkena wabah dan lain sebagainya. Dari dampak tersebut, maka berimbas pula pada tingkat kemiskinan masyarakat jawa timur yang mengalami peningkatan secara signifikan dikarenakan roda perekonomian banyak yang mancet akibat Pandemi Virus Covid-19. Meskipun di kurun 5 tahun terakhir, maret 2020 tidak menunjukan angka kemiskinan yang sangat buruk dibanding dengan tahun sebelumnya dibulan maret 2015. Namun, hal tersebut jusru mampu membuat ekonomi terguncang dan mengakibatkan kemiskinan meningkat drastis dibulan maret 2020, jika dibandingkan dengan bulan dan tahun sebelumnya. Hal tersebut sejalan dengan penelitian terdahulu yang dilakukan oleh alif et al. Dimana dalam penelitiannya menunjukkan bahwasannya covid 19 juga memberikan dampak terhadap kemiskinan di Indonesia pada kurun waktu september 2019 hingga akhir tahun 2020 pada angka $9,7 \%$. Tak hanya itu saja, hal yang sama juga dijelaskan dalam buku dirjen kebijakan fiskan kemenkeu UNICEF. Dimana, hal yang sama terjadi ketika masyarakat yang produktif terpaksa kehilangan pekerjaan atau pendapatan dikarenakan dampak covid 19. Maka hal yang tak diinginkan seperti kemiskinan akan meningkat ditahun 2021. Dimana, UNICEF memprediksi bahwa kemiskinan akan meningkat sebesar 2,1 juta di tahun 2021.

Berkaitan dengan data dan keterangan diatas menunjukkan bahwasannya kemiskinan digunakan sebagai ukuran atau batas guna mengelompokkan beberapa penduduk menjadi kategori pendudukmiskin atau penduduk tidak miskin. Penduduk yang dikatakan miskin berarti penduduk tersebut mendapatkan penghasilan dibawah standar yang ditetapkan pemerintah dan memiliki keterbatasan didalam hal untukmemenuhi kebutuhan sandang, pangan, dan papan, dalam kehidupan sehari-harinnya.

Tabel 3. Garis Kemiskinan dan Perubahannya Menurut Daerah, Maret 2019-Maret 2020

\begin{tabular}{lccc}
\hline \multirow{2}{*}{ Daerah/Tahun } & \multicolumn{3}{c}{ Garis Kemiskinan (Rp/Kapita/Bulan) } \\
\cline { 2 - 4 } & Makanan & Bukan Makanan & Total \\
\hline Perkotaan & $(2)$ & $(3)$ & $(4)$ \\
\hline Maret 2019 & 305759 & 105971 & 411731 \\
\hline September 2019 & 310555 & 108014 & 418570 \\
\hline Maret 2020 & 317234 & 110942 & 428175 \\
\hline Perubahan Mar'19 - Sept'19 (\%) & 1,57 & 1,93 & 1,66 \\
\hline Perubahan Sept'19-Mar'20 (\%) & 2,15 & 2,71 & 2,29 \\
\hline Perdesaan & & & 382327 \\
\hline Maret 2019 & 290587 & 91740 & 388075 \\
\hline September 2019 & 294266 & 93809 & 402503 \\
\hline Maret 2020 & 306255 & 96247 & 3,50 \\
\hline Perubahan Mar'19 - Sept'19 (\%) & 1,27 & 2,26 & \\
\hline Perubahan Sept'19 - Mar'20 (\%) & 4,07 & 2,60 & 397687 \\
\hline Total & & & 404172 \\
\hline Maret 2019 & 298341 & 99346 & 416001 \\
\hline September 2019 & 302757 & 101415 & 1,63 \\
\hline Maret 2020 & 311891 & 104110 & \\
\hline Perubahan Mar'19 - Sept'19 (\%) & 1,48 & 2,08 & \\
\hline
\end{tabular}


Anis Rahmawati, L. Lutfiani, Zulvita R. Yunia, Isma'iddatur Rofiqoh, Fitri F. Zahrok, \& D. Wahyuningtyas.

\begin{tabular}{cccc}
\hline Perubahan Sept'19 - Mar'20 (\%) & 3,02 & 2,66 & 2,93 \\
\hline $\begin{array}{l}\text { Sumber: Diolah dari data Survei Sosial Ekonomi Nasional } \\
\text { (Susenas) Maret 2019, September 2019 dan Maret 2020 }\end{array}$ &
\end{tabular}

Selain kemiskinan, hal lainnya yang menjadi indikator yang terkena dampak Pandemi Virus Covid-19 yakni ketimpangan. Ketimpangan menunjukan suatu masalah kompleks yang dipengaruhi oleh banyak aspek. Aspek tersebut bukan hanya dari sumbar daya manusia saja, melainkan aspek alam juga mempengaruhi seperti potensi sumber daya alam dan karakteristik geografis. Dengan tidak meratanya pembangunan daerah di Indonesia dapat menyebabkan ketimpangan ekonomi antar suatu daerah tertentu dengan derah atau wilayah lainnya. Berikut data ketimpangan Jawa Timur :

Tabel 4 Data Gini Ratio Ketimpangan Provinsi Jawa Timur Maret 2019-Maret 2020

\begin{tabular}{lllllllll}
\hline \multicolumn{3}{c}{ Maret 2019 } & \multicolumn{3}{c}{ September 2019 } & \multicolumn{3}{c}{ Maret 2020 } \\
\hline Kota & Desa & K+D & Kota & Desa & K+D & Kota & Desa & K+D \\
\hline 0,379 & 0,318 & 0,370 & 0,374 & 0,314 & 0,364 & 0,377 & 0,316 & 0,366 \\
\hline \multicolumn{3}{c}{ Sumber: Bps Jawa Timur 2020 (diolah) }
\end{tabular}

Berdasarkan data Gini Ratio diatas menunjukkan perkembangan yang sangat baik dari bulan ke bulan berikutnya. Hal tersebut terlihat, bahwasannya di perkotaan pada bulan maret 2019 diangka 0,379, dan kemudian pada september 2019 menjadi 0,374 menunjukkan penurunan nilai Gini Ratio. Hal tersebut menunjukkan perkembangan yang baik, dimana pengurangan Gini Ratio berarti di perkotaan untuk wilayah jawa timur terjadi perbaikan dalam hal pemerataan pengeluaran. Hal tersebut tentu, sangat berpengaruh terhadap pendapatan masyarakatnya yang cenderung merata dan mengalami kemakmuran.

Selain data perkotaan tersebut, kemakmuran atau pemerataan pendapatan juga terjadi di desa. Dimana pada data tersebut terlihat di bulan maret 2019 nilai Gini Ratio nya yakni 0,318. Sedangkan untuk bulan september 2019 menunjukkan angka 0,314. Terdapat selisih lebih baik dibandingkan bulan sebelumnya sebesar 0,004 . Hal tersebut juga menunjukkan hal yang baik dan positif bagi perkembangan pemerataan pendapatan diwilayah pedesaan. Dengan meratannya pendapatan masyarakat pedesaan, maka, kemakmuran yang diharapkan dapat tercapai dengan baik.

Namun, pada data tersebut, perkembnagan Gini Ratio rupannya mengalami kenaikan yang cukup banyak di bulan maret tahun 2020. Yang mana pada saat itu terjadi pada masyarakat seluruh dunia. Tak terkecuali Indonesia merasakan dampak dari menyebarnya virus Covid 19. Dimana masyarakat yang sebelumnya merasa ketimpangan yang cenderung mendekati 0 atau nyaris pemerataan pendapatan merata. Kini justru mengalami perbedaan atau kesenjangan yang diluar dugaannya. Dimana pada maret 2020 Gini Ratio mengalami kenaikan, yang menyebabkna perubahan rasio dari september 2019 yakni 0,374 untuk wilayah kota, berubah menjadi 0,377 pada maret 2020. Terjadi perubahan atau kenaikan Gini Ratio sebanyak 0,003 basis poin. Sedangkan untuk wilayah pedesaan juga demikian, dimana pada september 2019 Gini Ratio berada di nilai 0,314 menjadi 0,316 dibulan maret 2020. Hal tersebut menunjukka kenaikan sebesar 0,002 basis poin. Hal tersebut sejalan dengan penelitian terdahulu yang dilakukan oleh alif et al. Dimana dalam penelitiannya menunjukkan bahwasannya 
Anis Rahmawati, L. Lutfiani, Zulvita R. Yunia, Isma'iddatur Rofiqoh, Fitri F. Zahrok, \& D. Wahyuningtyas.

covid 19 juga memberikan dampak terhadap ketimpangan di Indonesia pada kurun waktu september 2019 hingga akhir tahun 2020.

Dari data tersebut menunjukkan pengaruh pandemi covid 19 begitu berdampak terhadap ketimpangan di wilayah jawa timur. Dimana, kenaikan beberapa basis poin tersebut justru berdampak buruk pada ketimpangan jawa timur. Meningkatnya Gini Ratio menjadi sebuah tanda adannya pendapatan yang mengalami ketimpangan. Dimana pendapatan tersebut hanya diterima oleh sekelompok orang saja dan tidak merata ke semua orang yang ada di daerahJawa Timur. Hal itu rupannya menjadi sebuah pertanda. Dimana menyebarnya virus Covid 19 diwilayah jawa timur memberikan imbas yang signifikan terhadap penyebaran pendapatan masyarakat jawa timur.

\section{SIMPULAN}

Pandemi Virus Covid-19 memilki pengaruh yang cukup besar terhadap bermacammacam sektor. Di era ekonomi global saat ini pandemi Virus Covid-19 telah menimbulkan berbagai dampak yang cukup signifikan di sektor perekonomian domestic dan pada keberadaan UMKM di negara dan bangsa. Dampak dari Covid-19 yang sudah menyebabkan economic shock, juga sangat berpengaruh terhadap ekonomi,baik secara perorangan usaha mikro kecil menengah, perekonomian negara yang mencangkup dari local, nasional serta global. Hal tersebut, tak juga berdampak pada kemiskinan dan ketimpangan yang juga turut serta terkena dampak dari pandemi Covid 19. Dimana, dalam hal ini menyebabkan kemiskinan di jawa timur mengalami kenaikan sedangkan ketimpangan dimasayarakt juga mengalami kenaikan. Hal tersebut tentunnya sangat berdampak buruk bagi keberlangsungan perekonomian masyakat jawa timur khususnya dan masyarakat Indonesia pada umumnya.

Untuk dapat mengantisipasi dampak dari pandemi covid-19 terhadap pembangunan ekonomi disektor kemiskinan dan ketimpangan, pemerintah dapat mengupayakan dengan meningkatkan usaha mikro kecil dan menengah (UMKM) di masyarakat, untuk meningkatkan perekonomian negara dan masyarakat. Adanya usaha mikro kecil dan menengah (UMKM) ditengah masyarakat dapat mengurangi kemiskinan dan ketimpangan bagi warga negara Indonesia, serta pemerintah dapat memberikan sumbangan dana bagi usaha mikro kecil dan menengah (UMKM) untuk dapat melakukan pengembangan usaha yang dimiliki masyarakat akibat pandemi covid- 19 seperti yang terjadi saat ini yang menimbulkan dampak terhadap pendapatan warga masyarakat Indonesia.

\section{DAFTAR RUJUKAN}

Arsyad, Lincolin. 2010. Ekonomi Pembangunan. Jakarta: Ghalia Indonesia.

Ayuningtyas, Taufik Eka Avianti. 2020. Dampak Pandemi Covid-19 Terhadap Bisnis dan Eksistensi Platform Online", Vol. 22 No. 01. Jakarta: Sekolah Tinggil Imu Ekonomi, 30 April.

Damarjati, Danu. Data Corona Terkait Indonesia, 30 April 2020 Per Pukul 16.00 WIB, Availabel at. https://news.detik.com/berita/d-4997618/data-corona-terkait-indonesia-30-april-2020-per-pukul1600-wib

Ilham, Muhammad. 2011-2015. Analisis Ketimpangan Ekonomi Menurut Provinsi Di Indonesai.

Moleong, Lexy J. 2009. Metode Penelitian Kualitatif. Bandung : PT. Rwmaja Rosdakaya. 
Anis Rahmawati, L. Lutfiani, Zulvita R. Yunia, Isma'iddatur Rofiqoh, Fitri F. Zahrok, \& D. Wahyuningtyas.

Murni, Asfia. 2006. Ekonomi Makro Pertumbuhan Ekonomi dan Kebijakan Makro. Bandung: PT Refika Aditama

Pahan, Aknolt Kristian Pak. Covid-19 dan Implikasi Bagi Usaha Mikro, Kecil, danMenegah. Bandung: Fakultas IImu Sosial dan IImu Politik, Universitas Katolik Parahyangan.

Pangiuk, Ambok. 2018. Pengaruh Pertumbuhan Ekonomi Terhadap Penurunan Kemiskinan Di Provinsi Jambi Tahun 2009-2013 ", Vol. 02 No. 02. Sumatra: Fakultas Ekonomi dan Bisnis Islam UIN STS Jambi.

Subagiyo, Rokhmat. 2017. Metode Penelitian Ekonomi Islam Konsep dan Penerapan,. Jakarta: Alim's Publishing.

Subri, Mulyadi. 2003. Ekonomi Sumber Daya Manusia dalam Prespektif Pembangunan, edisi satu. Jakarta: PT. Raja Grafindo.

Suryahadi, Asep, Ridho Al Izzati, Daniel Suryadarma. 2020. Kemiskinan \& Ketimpangan Indonesia Kertas Kerja draf.

Tambunan, Tulus T.H. 2003. Perekonomian Indonesia: Beberapa Masalah Penting. Jakarta: Ghalia Indonesia.

Todaro, Michael, P, Smith, Stephen C, 2003. Pembangunan Ekonomi Di Dunia Ketiga Edisi Kedelapan. Surabaya: Erlangga.

Umiyati, Syahrur Romi, Etik. 2018. Pengaruh Pertumbuhan Ekonomi dan Upah Minimum Terhadap Kemiskinan di Kota Jambi", Vol. 07 N0. 01. Jambi: Prodi Ekonomi Pembangunan Fakultas Ekonomi dan Bisnis Universitas Jambi.

UNICEF. 2021. Ringkasan Kebijakan Dampak Covid-19 Terhadap Kemiskinan Dan Mobilitas Anak Di Indonesia. Kebijakan Fiskal Kemenkeu UNICEF. 